\title{
MAGNETIC RESONANCE IMAGING IN HTLV-I ASSOCIATED MYELOPATHY
}

\author{
AILTON MELO*, LUCIANA MOURA**, SOLANA RIOS*, MARCOS MACHADO***, \\ GERSONITA COSTA ***
}

SUMMARY - Magnetic resonance imaging of the brain and spinal cord were carried out for seventeen consecutive patients with HTLV-1 associated myelopathy (HAM). Eight patients had brain abnormalities and four had decreased thoracic spinal cord diameter. Brain lesions were mostly located in subcortical and periventricular areas. Our data suggest that diffuse central nervous system lesions are present in patients with HAM.

KEY WORDS: HTLV-1, myelopathy, leukoencephalopathy, MRI.

Ressonância magnética na mielopatia associada uo HTLV-1.

RESUMO - Foram realizados exames de ressonáncia magnética do crânio e coluna em 17 pacientes com diagnóstico clínico laboratorial de mielopatia por HTLV-1 (HAM). Em oito pacientes havia anormalidades cerebrais caracterizadas por lesões subcorticais e peirventriculares. Quatro pacientes apresentavam diminuição acentuada do diâmetro da medula espinal torácica. Nossos dados sugerem ser a HAM uma patologia multifocal que envolve todo o sistema nervoso central.

PALAVRAS-CHAVE: HTLV-1, mielopatia, leucoencefalopatia, ressonância magnética.

It is now well established that HTLV-1 associated myelopathy (HAM) is an endemic disease in the Southwestern Japan, Caribbean Islands, Central Africa and Latin America $7,9,10$ but it also has been described in the United States and Europe 3,8 characterizing a disease of wideworld distribution. With magnetic resonance imaging (MRI), high intensity signals have been observed more frequently on T2-weighted imaging in patients who have white matter lesions as multiple sclerosis, leukodystrophies, some elderly people and in Binswanger subcortical arteriosclerotic encephalopathy 2,5,12, Recently some authors have described peri. ventricular white matter lesions in HAM and suggested possible sharing of ethiopathogenic mechanisms with multiple sclerosis which has been denied by others 4,6 .

The present study was designed to establish the types of MRI lesions in patients with HAM.

\section{METHODS}

The subjects of the present study were 17 consecutive patients who have been seen in a hospital which assist the lower socioeconomic class in Salvador. Five men and 12 women, with ages ranging from 18 to 52 years old, were selected according to accepted clinical criteria of HAM, including progressive spastic paraparesis, urinary urgence or incontinence, constipa-

* Federal University of Bahia (UFBA) and Santo Antonio Hospital; ** UFBA; *** São Rafael Hospital - Salvador. Aceite: 24-janeiro-1993,

Dr. Ailton Melo - Deplartamento de Neuropsiquiatria, Faculdade de Medicina, UFBA - Av. Reitor Miguel Calmon $\mathrm{s} / \mathrm{n}$ - 40110-100 Salvador BA - Brasil. Fax 55.71.2458562. 
tion and back pain sometimes associated with superficial sensitive syndrome, None of the patients had concomitant diabetes, heart diseases or arterial hypertension.

Laboratory. Serum and CSF samples were tested for antibodies to HTLV-1 using commercially available enzyme immunoassay (EIA). EIA repeatedly reactive samples were further examined using a HTLV-1 viral and recombinant proteins as an antigen source. Samples were considered serologically positive if antibodies against both the gag (p24) and env (p21E) gene products were present. The CSF from all participants were tested for the presence of antibodies against syphilis, toxoplasmosis, schistosomiasis and cysticercosis.

Imaging. Brain and spinal cord MRI were performed with a 0.6-t superconductive unit image with mu'ti-slice, multi-echo (SE) pulse sequence. Brain MRI was imaged in axial plane. Sagittal and coronal images were occasionally obtained as well. The slice thickness was $5 \mathrm{~mm}$ without interslice gaps. The acquisition matrix was $256 \times 256$. The MR studies of cervical and thoracic spinal cord were done with multi-slice, multi-echo(SE) pulse sequence and field echo. The slice thickness was $5 \mathrm{~mm}$ without gaps, or $3 \mathrm{~mm}$ with $1 \mathrm{~mm}$ interslice gap. The exams were carried out in two differents hospitals.

\section{RESULTS}

Age at the onset of neurologic symptoms as judged from the history ranged between 17 and 45 years (mean age 32.4 years).

Abnormalities detected by MRI are summarized in Table 1. Ten (58.8\%) of 17 patients with HAM had abnormalities on brain, thoracic spinal cord or both.

Among patients studied, 8 (47\%) had brain abnormalities and 4 (23.5\%) had markedly decreased diameter of thoracic spinal cord. Two patients had brain and spinal cord lesions. Five patients had positive periventricular lesions. Subcortical brain abnormalities were found in three patients and three shared both subcortical and periventricular lesions. Figure 1 shows: periventricular brain radiologic abnormalities in a 45 year old patient with HAM for 12 years; several large and confluent lesions near the anterior land pasterior horns as well as subcortical lesiors in a 42 old woman with HAM for 18 years. In four patients thoracic spinal cord thickness was heavily reduced as shown in Figure 2.

In none of the patients lesions in the cerebellum or brain stem were found.

\section{COMMENTS}

The present cases of HTLV-1 associated myeolapathy showed an uniform clinical picture as previously reported 3 but some radiological abnormalities point to different grades of an unique disease. Our patients exhibited e neurological disorder with brain and spinal cord involvement as determined with MRI. Brain lesions were multifocal but predominated in periventricular and subcortical areas of the brain.

Although intraparenchymal spinal cord lesions have been previously described 11 none of our patients had these kind of lesions. The conspicuous de-

Table 1. MRI findings in the central nervous system of 17 patients with HAM.

\begin{tabular}{|c|c|c|}
\hline Item & Number of cases & $\%$ \\
\hline Normal & 7 & 41.2 \\
\hline Brain abnormalities & 8 & 47.0 \\
\hline Periventricular lesions & $\mathbf{5}$ & 35.2 \\
\hline Subcortical lesions & 3 & 17.6 \\
\hline Both & 3 & 17.6 \\
\hline Decreased thoracic spinal cord diameter & 4 & 23.5 \\
\hline
\end{tabular}




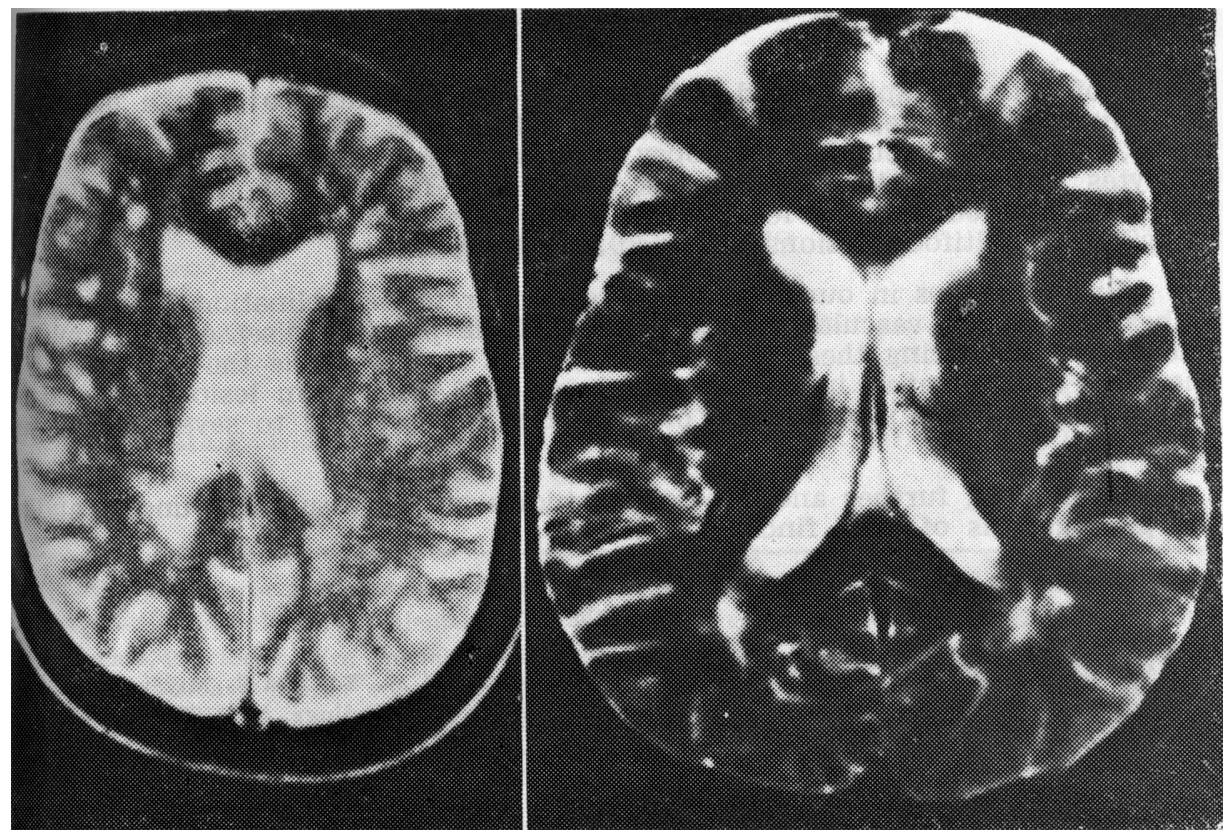

Fig. 1. Examples of periventricular white-matter high intensity leslons detected by T2-weighted MR: lesions around occlpital horns; subcortical and periventricular lesions.

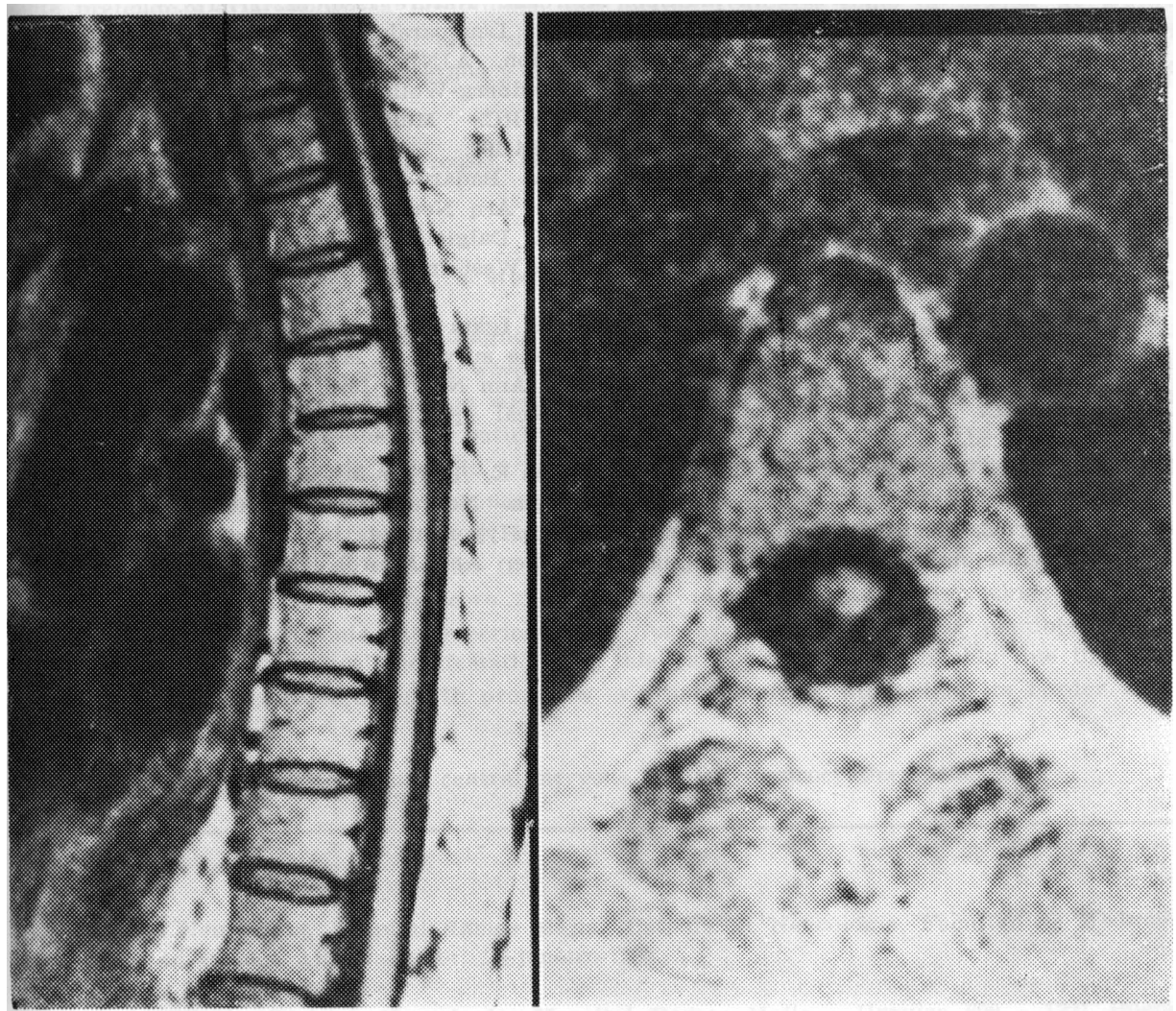

Fig. 2. Marked reduction of the thoracic cord thickness: sagittal and transversal vlew. 
crease of thoracic spinal cord diameter is probably due to a high degree of demyelination and degeneration of pyramidal, spinocerebellar and spinothalamic tracts, as has been found in necropsy studies 1 . The perivascular cuffing of lymphocytes throughout the CNS as has been pointed out in necropsies 1 suggests that vasculitis could be a feature of the pathology of patients with HAM and explain the multifocal lesions observed in these patients.

Brain changes in our patients were similar to demyelination lesions found in healthy elderly, vascular problems and also in primary diseases like multiple sclerosis. Considering these different situations it is possible that different mechanisms are operative in the MRI findings of HAM. Brain lesions showed no correlation with the age of onset of HAM but were related to severity of symptoms.

Meanwhile, further and controlled studies are necessary for understanding the pathogenesis of MRI findings in HAM.

\section{REFERENCES}

1. Akizuki S, Nakazato $O$, Higuchi $Y$, Tanabe $\mathbf{K}$, Setohuchi M, Yoshida S, Miyazaki $\mathbf{Y}$, Ymamoto $\mathbf{S}$, Sudou $\mathbf{S}$, Sannomiya $\mathbf{K}$, Okajima $\mathbf{T}$. Necropsy findings in HTLV-1 associated myelopathy. Lancet 1987, 1:156-157.

2. Berger J, Tornatore C, Major EO, Bruce J, Shaphak P, Yoshioka M, Hauff S, Sheremata W, Morton GF, Landy $H$. Relapsing and remitting human immunodeficiency virus associated leukoencephalomyelopathy. Ann Neurol 1992, 31:34-38.

3. Janssen RS, Kaplan JE, Khabbaz RF et al. HTLV-1 associated myelopathy/tropical spastic paraparesis in the United States. Neurology 1991, 41:1355-1357.

4. Karpas A, Kampf V, Siden A, Koch M, Poser S. Lack of evidence for involvement of known human retroviruses in multiple sclerosis. Nature 1986, 322:177-178.

5. Kobart M, Meyer JS, Ichijo M, Oravez WT. Leukoaralosis correlation of MR and CT findings with blood flow, atrophy and cognition. AJNR 1990, 11:273-281.

6. Koprowskd H, DeFreitas EC, Harper ME, Sandberg-Wollhelm M, Sheremata WA, RobertGuroff M, Saxinger CW, Wong-Staal F, Gallo RC. Multiple sclerosis and human T-cell lymphotropic retroviruses. Nature 1985, 318:154-160.

7. Meireles A, Moreira ED, Moreno-Carvalho OA, Badaró R, Melo A. HTLV-1 associated myelopathy in Salvador (Northeastern Brazil). Arq Neuropsiquiatr 1992, 50:189-190.

8. Newton $\mathbf{M}$, Miller D, Rudge $\mathbf{P}$, Cruickshank $\mathbf{K}$, Dalgleish A, Clayden S, Moseley I. Antibody to human $T$-lymphotropic virus type 1 in West-Indian-born UK residents with spastic parariaresis. Lancet 1987, 1:415-416.

9. Osame M, Janssen RS, Kubota H, Nishitani H, Igata A, Nagataki S, Mari M, Goto I, Shimabukuro H, Khabaz R, Kaplan J. Nationwide survey of HTLV-1 associated myelopathy In Japan: association with blood transfusion. Ann Neurol 1990, 28:50-56.

10. Roman GC. The neuroepidemio'ogy of tropical spastic paraparesis. Ann Neurol 1988, $23($ Suppl) :S113-S130.

11. Sheremata WA, Quencer $R$, Gatti E, Defreitas E, Harper M, Koprowski H. Magnetic resonance imaging of tropical spastic paraplegia. Neurology 1987, 37 (Suppl 1):322.

12. Swieten JC, Geyskes GG, Derix MMA et al. Hypertension in the elderly is associated with white matter lesions and cognitive decline. Ann Neurol 1991, 30:825-830. 